\title{
Participatory Needs Assessment in Local Development: Rhetoric or Reality A Case of Putalibazaar, Syangja
}

Amrit Kumar Bhandari

\section{Abstract}

Based on the firsthand data collected through fieldwork, this article highlights the rhetoric and reality of people's participation in the local development activities in Putalibazaar Syangja. Concentrating on the foundational aspect of participatory development i.e. needs assessment, this article explains that the needs assessment program being practiced by Putalibazaar Municipality is weaker and ineffective one. In the name of participatory planning, there has been the domination of the leader-centric approach as opposed to the people-centric one in needs assessment. Thus, this article posits that people's participation in development activities in Putalibazaar is more rhetoric than reality.

Keywords: participatory planning, participatory development, needs assessment, urbanization

\section{Prelude}

In the agendum of development, participation has been one of the popular slogans and popular development tools. As Rahnema (1997) holds "As it stands now, participation is a most accepted concept which even very repressive regimes in the 'Third World', such as the ones led by Pinochet and Mobutu, have tried to promote as one of their objectives (p. 157)".

Today, participatory development has been regarded as an important social technology of knowledge creation process that starts right from grass-root level of the societies (Devkota, 1999:102). In Nepalese context too, the issue of people's participation often finds a pivotal place in the yearly or other periodic planning of all local development bodies. Whether or not it has been able to bring the real fruits of development to Nepalese people, it is overwhelmingly talked about and given an unprecedented emphasis by planners, developers, political activists, intellectuals, and others.

Putalibazaar, a designated urban area as municipality, is a gradually urbanizing setting of western Nepal. It catches significant development interest from 
various agencies as it is the district headquarter of Syangja. However, covering a relatively large area of 70.14 square kilometers, Putalibazaar has been a challenging prospect from infrastructural development point of view.

\section{Problem}

The Putalibazaar municipal authority here claims of endeavoring to foster development within its boundary by formulating yearly plans. But considering the low level of infrastructural development (low level in terms of fulfilling local people's development aspirations) in the municipality in more than fifteen years of its formation, the need assessment and the implementation of the plans made by the municipality deserves significant questioning. This becomes even more important in the context that municipality stressfully claims of adopting participatory planning and development. Based on the findings of the research, this article tries to assess rhetoric and reality of participatory development in the Putaliubazaar area.

\section{Concept of Participatory Development}

Participatory development is a process through which stakeholders can influence and share control over development initiatives, and over the decisions and resources that affect themselves (ADB, 1996). Governmental organizations, local bodies, NGOS, and INGOs are found to be emphasizing this issue quite stressfully while formulating, implementing and assessing impacts of development activities. It is believed that this development is a tool for strengthening the sense of ownership among local people towards the development initiatives being carried out in their setting. In this context, Rietbergen-McCracken (n.d.) mentions that "the core aims of participatory development planning are to give people a say in the development decisions that may affect them and to ensure that development interventions are appropriate to the needs and preferences of the population that they are intended to benefit."

Participating in formulating the fundamental goals as well as in planning and carrying out an activity empowers stakeholders and fosters a sense of ownership. These facilitate effective project implementation, conscientious monitoring of activities, and sustainable outcomes. Effective poverty reduction also requires greater flexibility in responding to problems and unexpected opportunities throughout project development, 
implementation, and monitoring. Responsiveness and collaboration among intended beneficiaries, government, civil society, and the private sector at local, intermediate (district, province, etc.) and national levels promote social capital development and sound governance (ADB, 1999).

\section{Concept of Participatory Planning}

Participatory planning can be defined as a tool for identifying the needs of all individuals within a community, a way of building consensus, and a means of empowering disadvantaged or disenfranchised groups (World Bank, 2011).As stated by Oltheten (1999), participatory planning is the initial step in the definition of a common agenda for development by a local community and an external entity or entities. Over the period, this initial step is expected to evolve for the parties concerned towards a selfsustaining development planning process at the local level.

According to World Bank (2011), the main advantages of having participatory plans done at the municipal (rather than only at the community) level are:

- It allows scaling up and mainstreaming of community driven development principles into government planning at the local level, leveraging not just the social fund resources but local governments' resources as well.

- The territorial boundaries of a local government usually capture the network and economies of scale characteristics of most local investments (such as tertiary roads, health posts, primary schools, etc.).

- Quality of plans and investment improves through greater coordination of sectoral investments (by reducing incentives for multiple and parallel planning and funding systems), and a better connection between community preferences and technical sector expertise.

- Increased sustainability of investments by linking them with local governments.

- Greater transparency and accountability of public decision-making and management. A good planning methodology allows all communities the opportunity to participate, follows transparent criteria and processes for prioritization, and includes mechanisms to hold local government accountable for plan implementation. 


\section{Study Area and Methods}

This article was prepared based on a research carried out in Sataun and Lamage areas of Putalibazar municipality, which currently lie at the ward no. 8 and 9 of the municipality respectively. These areas are located at the western vicinity of the municipality and include 988 households: 491 households of ward no. 8 and 497 of ward no. 9 of Putalibazaar municipality. Brahman, Chhetri, Sanyasi, Gharti, Dalits (Biswokarma, Pariyar, Nepali, Gandharba), Gurung, Magar and Newar form the major portion of population. From religious point of view, this area is inhabited by Hindus, Muslims and Buddhists. Data were collected by employing research techniques of interview, observation (both participant and nonparticipant), and focused group discussion. This article is mainly based on the analysis of collected qualitative data.

\section{Discussion of the Findings}

\section{An Experience from a Ward Bhela: A Highlight of Needs Assessment Program}

During the field work, the researcher got an opportunity to participate and witness one of such ward meetings of PBM-9 at Jhaphati, Lamage. Popularly known as Ward Bhela in public tongue, they are meant to assessing the needs of people, documenting their demands regarding the formulation of various plans and programs for the coming fiscal year for the development of the ward. The ward assembly had invited all people across the ward and the people were present there in significantly larger number. However, the assembly was largely revolved around 4-5 persons who were the local leaders of the main three political parties characterizing the scenario of whole Nepal. People were gathered around these leaders who were busy in amassing their supporter's demands. Besides, some of the local intellectuals were directly registering their demands in the meeting without taking any leaders side. Supporters of different parties were also noted to be in consensus when the matter of their tole/locality appears on the scene. Initially people were presenting an attacking tone saying their demand was largely ignored by the previous year's urban planning.

The representative of the municipality office was busy in resisting people's strong voices and enlisting the needs of people. He was trying to convince people that he was not responsible for formulating development plans but he would present all the demands made by people to the concerned 
authority. The local intellectuals and political leaders were also promising local people to strengthen their lobbying to bring more programs to the ward. After the heated discussions of about 3 hours, the assembly concluded. But at the end, when the researcher talked to the people informally, they were saying that the ward assembly was just a formality, plans would not be made as per their aspirations. Only those who would be able to influence the concerned authorities at the municipality office would be able to snatch the budget. Surely such kinds of meetings would never be able to address real aspirations and needs of people for years; needs assessment and development activities have been running in this way.

An interview with a key-informant from ward no. 8 revealed that the ward bhela in this ward also occurs in the similar way as that in ward no. 9. More important fact revealed by local people during discussion was that this kind of ward bhelais a reflection of those carried out in the past not only in these two wards but also in the other eleven wards of this municipality. It means formulating local needs in that way has been a popular trend not only in the study area but also in the whole Putalibazaar.

The cases of these two wards clearly indicate that participatory needs assessment is largely a misunderstood process. Concerned local body is happy to follow the traditional practice and local people are much more reluctant towards making the assessment program really participatory and beneficial one.

\section{a. Needs Assessment and Gender Issues}

Needs assessment program should be participatory and inclusive one to ensure the involvement of all concerned parties. On the day of ward meeting or official need assessment program in ward no. 9, I was in Amdanda, a locality situated in this ward. The place for the meeting Jhaphati was about 25 minutes' walk from Amdanda. Local men were seen to be talking more about the meeting than the local women as if the agendum of the meeting was of men only. Women were not showing significant concern. When asked a local woman about not attending the meeting, she replied that she was not going to have a headache by engaging in men's activities. Later on when observed during the meeting, the attendance of women was paltry. Only a few women from nearby households were seen watching the whole scene as mere spectators. 
The picture of the meeting has already been explained. So, it can be argued that the need assessment program was largely male-dominated and greatly gender biased. When asked a local elite about the lack of women's participation in the meeting, he replied that women were not able to raise their voice effectively enough. However, he added that women's issues have been incorporated (by men). Here too, the orthodoxy of patriarchy was evident.

\section{b. Needs Assessment and Caste/Ethnicity Issues}

The study area (both wards) is chiefly inhabited by Chhetri, Brahman, Thakuri, Gharti, B.K. Pariyar, Ghanderva and Muslim. So, it is quite realistic to assume the representation of people of all of these caste/ethnic groups. In terms of attendance, there was representation of all the caste/ ethnic groups but the participation was quite passive one. They were divided into the groups formed on the basis on political parties they were affiliated to. Thus, they were just witnessing what the political leaders were doing. When the municipality representative was asked about this issue, he replied that caste/ethnic issues have well been incorporated. This answer looked quite a readymade one.

Considering the fact that the municipality is relatively young, it makes sense that it has a lot to do regarding formulating and implementing effective participatory planning. The practices that have been done so far can be valuable learning curve based on which time specific effective planning can be formulated and implemented.

\section{c. Needs Assessment and Participation of Youths}

Youths are considered as the agents of change. In the study area, out migration of youths has been ever increasing phenomenon in the last 10-15 years citing a number of reasons like for higher studies, for employment, etc. During the field work, it was recorded that at least one youth had out migrated from each household of these two wards. In the lack of youths, the needs assessment in these places has largely remained a stereotype. The participants of the ward meeting as mentioned above, were largely elderly people above 40 years or even more, for whom development is largely about constructing trails, managing water supply, constructing school building, etc. Their insights, experiences and skills are still revolved around such development activities as evidenced in the annual program designed by the municipality in the past years. They may not be well aware about the actual needs for the local setting 
to urbanize it as per the demand of the changed context. It is not fair to blame them regarding this. As one of the local teachers mentioned that the absence of youths has been a significant hindering factor for effective urbanization in this area. Had they been in the ward meeting, they could have formulated the needs for the area as consistent with the changed time. As a result, urbanization process would have fostered.

\section{Participation of Local People in the Implementation of Development Activities}

Effective need assessment is most likely to produce an effective people's participation in local development undertakings. After getting an insight to the prevailing needs assessment practice during ward bhela, during the field work the researcher had inquired the sampled 278 households about the nature of their participation in local development activities during implementation in the past. In this inquiry,only about one-fourth of the respondent households claimed that they participated in the implementation of most of the development activities carried out in their setting till that period. But a large i.e. about two-third of the households said that they participated only in some of the development programs. Here, it is clear that the number of households participating in almost all development programs is significantly less than those participating in some of these activities.

Keeping in mind the real thirst of development and urbanization in the study area, it can be argued that the level of participation of local people has been much below the expected one. A significant reason for this lack of effective participation of local people in development activities is the lack of people-centric or people-friendly needs assessment programs. This is because had the need assessment been effective, the development agenda would have been spelled out by the local people themselves; as a result the sense of accountability and feeling of ownership towards development would have greatly increased. This would have surely uplifted the level of urbanization in the study area.

\section{Lack of Effective Utilization of the Allocated Development Budget}

According to the PutalibazaarMunicipalityOffice record, a total of Rs. 910,000/- was allocated by the municipality council as development budget for two of its wards i.e. ward no 8 and 9 in the Fiscal Year (FY) 2065/66. But about 10 percent of this budget i.e. Rs. 90,000/- remained unused 
or freeze. The following municipal council allocated Rs. 1,210,000/- as development budget of these wards in the FY 2066/67. In the end of this FY, about 3.3 percent of the budget remained freeze. Similarly, municipal council of the FY 2067/68 allocated Rs. 790,000/- on the same heading for these two wards, but in that year also all development budgets could not be utilized. This time about 9 percent of the budget remained freeze.

During the field work, it was understood that a large number of local were unaware about the allocation of development budget in their area. This is largely the result of ineffective need assessment conducted by the municipality. Since, local people's participation was mere a formality during need assessment, budget allocation and effective utilization was not clear in the public mind. Here, the local political parties, which are active in the study area should have been more conscious about this just like they were during the needs assessment. Their role has not been that much productive regarding launching the instrumental development campaign in the study area.

\section{Conclusion}

Putalibazaar municipality authority stressfully claims that it has been practicing participatory local development since its formation. Its annual programs also speak the same fact. However, the in-depth analysis of the needs assessment programs carried out by it clearly signals that development is yet to be a real participatory one. More often, development needs for a locality are spelled out by political leaders though they had to be spelled out by local people themselves. Gender and caste/ ethnic issues are yet to get deserved attention. The dearth of youths has adversely affected people's friendly and time-specific needs assessment. The immediate consequence of weak and ineffective needs assessment is demonstrated by the relatively weaker level of participation of local people in development activities and the lack of effective utilization of development budget. Allocating budget is only one task, more important task is its proper utilization. Thus, it has been concluded that there is an urgent need of translating rhetoric of participatory development into a reality. For this, both the municipal authority and local people have to contribute effectively, realistically, honestly and positively from their part. 


\section{References}

ADB. (1996). Framework for Mainstreaming Participatory Development Processes into Bank Operations. Manila: Asian Development Bank.

Devkota, Padam L. (1999). "People-centered Development in Nepal: and Innovative Approach". Unpublished $\mathrm{PhD}$ Thesis, University of Delhi. Delhi: India.

Oltheten. Theo M.P. (1999). "Participatory Approaches to planning for Community Forestry". A synthesis report. Forests, Trees and People Programme, Forestry Department Working Paper No. 2.

Rahnema, Majida (1997). "Participation". In Wolfgang Sachs (ed) The Development Dictionary: A Guide to Knowledge as Power. New Delhi: Orient Longman Limited, pp. 1550-175

Rietbergen-McCracken, Jennifer. (n.d.). "Participatory Development Planning: Tool".In Policy and Planning, PG Exchange. Retrieved 14 ${ }^{\text {th }}$ October 2012 at http://www.pgexchange.org/ images/toolkits/PGX_F_Participatory\%20Development $\% 20$ Planning. pdf

World Bank. (2011): "Participatory Planning and Community Mobilization". In Social Funds: Design and Implementation. Operations Evaluation Department, Washington: World Bank. Retrieved http://go.worldbank.org/XR9I71AQV0 